\title{
Environmental Awareness of the College Students with respect to Sex and Faculty
}

\author{
Gunde R. V.1, Parit A. S.2
}

\section{ABSTRACT:}

The study has been undertaken to find out the effect of sex and faculty on Environmental Awareness of the college students. Environment Awareness Ability Measure (EAAM) constructed by Praveenkumar Zha was administered on 300 subjects; 100-100 students from arts, commerce and science faculties, half of them were male and half female. All students were First year college students from Gadhinglaj area of Kolhapur District. The data analyzed by using two-way ANOVA and further analyzed with Scheffe post hoc test. Results indicated that significant difference in environmental awareness was found for sex as well as faculty. But no significant interaction effect between sex and faculty found on environmental awareness of the college students.

Keywords: Environmental Awareness, sex, faculty, ANOVA and Scheffe post hoc test.

\section{INTRODUCTION:}

Now a day the global concern is to struggle against environmental pollution and maintain the standard of human environment. The industrial revolution, unprecedented scientific and technological revolution resulted in disastrous changes in the environment leading to environmental degradation crisis. By looking at the scopes and impacts of environmental problems, environmental awareness and attitudes have become very important concepts. While it is thought that the main source of many environmental problems is irresponsible behaviors of the people with respect to environment. It is important that human being must be aware of environmental problems and work for environmental protection and conservation. This is a fact that human beings need to raise awareness of environmental problems as a result of necessary trainings.

Environmental awareness is increasing of awareness and understanding of the environment through education. Most of our population is not aware of our finite resources and how quickly they are being used up. By its very definition, "awareness" means "having knowledge or cognizance." Environmental awareness is also defined as concern for what is happening in the environment. Students have always played an active role in the activities leading to the development of environmental awareness.

${ }^{1}$ M. A. M. Phil., Associate Professor, Dept. of Psychology, Shivraj College, Gadhinglaj, 416502.

${ }^{2}$ M. A. Ph. D., Guide and Head, P.G. Dept. of Psychology, Rajaram College, Kolhapur.

(C) 2015, R. Gunde, A Parit; licensee IJIP. This is an Open Access Research distributed under the terms of the Creative Commons Attribution License (http://creativecommons.org/licenses/by/2.0), which permits unrestricted use, distribution, and reproduction in any Medium, provided the original work is properly cited. 
Shobeiri et al (2007) found that there is no significant difference between boy and girl students in their level of environmental awareness. Boy and girl students in this study have the same level of environmental awareness and sex is not a factor, which affects environmental awareness. Ahuja (2010) conducted a study of environmental awareness among B Ed. trainee teachers of govt. aided and self financed colleges. The results reveal that sex, stream or faculty and type of residence of the B.Ed. teacher trainees did not differ significantly in their environmental awareness. Larijani (2010) conducted a study on environmental awareness of higher primary school teachers of Mysore City in India. Female teachers show significantly higher levels of environmental awareness as compared to their male counterparts.

Sengupta et al (2010) investigated the effect of stream (Arts, Science and Commerce) and sex on twelfth grade students' environmental awareness and environment related behavior in Kolkata. The effect of stream or courses of higher secondary syllabus showed that science students' scores on environmental awareness and behavior were less than that of arts students. The girl students are observed to be more environmentally aware although the sex has no effect on environment related behavior. Bhawana (2011) conducted a study on environmental awareness of B.Ed. students. This study reveals that there is no significant difference between the mean scores of environment awareness of male and female B.Ed. pupil teachers. There is no significant difference between the mean scores of environmental awareness of B.Ed. pupil teachers of Arts and Science streams. Kumar et al (2011) conducted a research on environmental awareness among senior secondary school students. The results show that there is significant influence of sex, type of school and faculty on the student's environmental awareness. Girls were found to be much aware about environmental issues than boys. Science stream students have high environmental awareness scores than Arts stream students.

\section{AIM OF THE STUDY:}

The aim of this study is to find out the effect of sex and faculty on environmental awareness of the college students.

\section{OBJECTIVES:}

1. To study the effect of sex on environmental awareness of the college students.

2. To determine the effect of faculty on environmental awareness of the college students.

3. To examine the influence of interaction between sex and faculty on environmental awareness of the college students.

\section{HYPOTHESES:}

1. The females are significantly more environmentally aware than the males.

2. Arts faculty students are significantly inferior to commerce faculty students in their environmental awareness.

3. Science faculty students are significantly superior to arts and commerce faculty students in their environmental awareness.

4. Interaction effect of sex and faculty on environmental awareness is not significant. 


\section{METHODOLOGY}

Sample- Sample of the study consisted 300 college going students from different colleges in Gadhinglaj area of Kolhapur district. Faculty and sex wise distribution was presented in Table 1.

Table 1 Faculty and sex wise distribution of the Sample

\begin{tabular}{|l|l|l|l|l|l|}
\hline \multicolumn{2}{|c|}{} & \multicolumn{2}{|l|}{ Faculty } & \multirow{2}{*}{} \\
\cline { 3 - 5 } \multicolumn{2}{|c|}{} & Arts(B1) & Commerce(B2) & Science(B3) & Total \\
\hline \multirow{3}{*}{ Sex } & Male(A1) & 50 & 50 & 50 & 150 \\
\cline { 2 - 5 } & Female(A2) & 50 & 50 & 50 & 150 \\
\hline Total & 100 & 100 & 100 & 300 \\
\hline
\end{tabular}

Tool used for data collection-Environment Awareness Ability Measure (EAAM) constructed by Pravinkumar Jha in 1998. The measure consists of 51 items. Every item is provided with two alternatives like agree and disagree. The reliability of the measure is 0.73 .

Procedure of data collection-The Ss selected from three different colleges, with permission of the Principals, Environment Awareness Ability Measure (EAAM) was administered without disturbing the time table of the college. The scale was distributed among the Ss and instructions were given to them. Though the scale requires 20 minutes, the filled response sheets were collected in time. The collected response sheets were manually scored and tabulated.

Design of the study-A balanced $2 X 3$ factorial design was used. The first factor was sex which varied at two levels namely male and female, whereas the second independent variable was faculty which varied at three levels namely arts, commerce and science. 


\section{RESULTS AND DISCUSSION}

In this study, two factors namely sex and faculties were considered as independent variables. On the basis of these two factors, the sample was distributed into six classified groups. Environmental Awareness was measured using EAAM. Means and SDs obtained by the six classified groups on environmental awareness are given in Table 2.

Table 2 Means and SDs of Six Classified groups

\begin{tabular}{|l|l|l|l|l|l|l|}
\hline & A1B1 & A1B2 & A1B3 & A2B1 & A2B2 & A2B3 \\
\hline Mean & 30.50 & 32.96 & 33.78 & 32.28 & 32.44 & 35.58 \\
SD & 4.22 & 4.15 & 3.81 & 3.95 & 3.70 & 4.13 \\
\hline
\end{tabular}

A1-Male, A2-Female, B1-Arts, B2-Commerce, and B3-Science

Inspection of the table 2 shows that mean values of the females are greater than the males mean values of environmental awareness. But it is not possible to draw conclusions confidently on the basis of means and SDs; the data were treated by two way ANOVA for environmental awareness is given in table 3 .

Table 3 Two way ANOVA for Environmental Awareness

\begin{tabular}{|l|l|l|l|l|}
\hline Source & $\begin{array}{l}\text { Type III Sum } \\
\text { of Squares }\end{array}$ & df & Mean Square & F \\
\hline Sex(A) & 78.03 & 1 & 78.03 & $4.88^{*}$ \\
Faculty(B) & 548.69 & 2 & 274.34 & $17.16^{* *}$ \\
Sex*Faculty & 88.94 & 2 & 44.47 & 2.78 \\
Error & 4699.58 & 294 & 15.98 & \\
Total & 5415.24 & 299 & & \\
\hline
\end{tabular}

*-significant at the 0.05 level

**-significant at the 0.01 level 
From the summery of table 3 for two way ANOVA, It shows that main effect of sex is significant $(\mathrm{F}=4.88$, df $=1$ and 294, $\mathrm{p}<0.05)$.it is clear that the factor of sex is effective in determination of environmental awareness. An examination of the mean values of the groups of males and females clearly shows that females have developed significantly better environmental awareness than the males. Results shown in table 2 and 3, it should be concluded that sex significantly affect on environmental awareness, and the females do better than males on environmental awareness. Thus, the hypothesis 'the females are significantly more environmentally aware than the males' is accepted.

The finding related to the sex and environmental awareness is in agreement with the findings of Larijani (2010), Sengupta et al (2010) and Kumar et al (2011). They found that the females are significantly better in environmental awareness than the males.

It is clear from the interaction effect of sex X faculty (A X B) that the main effect of sex and faculty function independently for environmental awareness. Interaction between sex and faculty does not show significant effect on environmental awareness of the college students $(\mathrm{F}=2.78$, $\mathrm{df}$ 2 and 294, $\mathrm{p}>0.05$ ).

Table 3 also indicates that the main effect of faculty shows effective in environmental awareness. It has been yielded an F value as 17.16; for 2 and $294 \mathrm{df}$ is significant beyond 0.01 level. It clearly indicates that faculty has significant effect on environmental awareness of the college students. Further the data were treated by Scheffe post hoc test for multiple comparisons of faculties to search whether the groups differ significantly from each other or not. The results are presented in and it is shown in table 4.

Table 4 Multiple Comparisons of faculty on Environmental Awareness (Scheffe)

\begin{tabular}{|c|c|c|c|c|c|c|}
\hline \multirow[b]{2}{*}{ (I) Faculty } & \multirow[b]{2}{*}{ (J) Faculty } & \multirow{2}{*}{$\begin{array}{l}\text { Mean } \\
\text { Difference } \\
\text { (I-J) }\end{array}$} & \multirow[b]{2}{*}{$\begin{array}{l}\text { Std. } \\
\text { Error }\end{array}$} & \multirow[b]{2}{*}{ Sig. } & \multicolumn{2}{|c|}{ 95\% Confidence Interval } \\
\hline & & & & & $\begin{array}{l}\text { Lower } \\
\text { Bound }\end{array}$ & $\begin{array}{l}\text { Upper } \\
\text { Bound }\end{array}$ \\
\hline \multirow[t]{2}{*}{ Arts } & Commerce & 1.31 & .57 & .070 & 2.70 & .08 \\
\hline & Science & $3.29^{* *}$ & .57 & .000 & 4.68 & 1.90 \\
\hline \multirow[t]{2}{*}{ Commerce } & Arts & 1.31 & .57 & .070 & .08 & 2.70 \\
\hline & Science & $1.98^{* *}$ & .57 & .002 & 3.37 & .59 \\
\hline \multirow[t]{2}{*}{ Science } & Arts & $3.29^{* 2}$ & .57 & .000 & 1.90 & 4.68 \\
\hline & Commerce & $1.98^{* *}$ & .57 & .002 & .59 & 3.37 \\
\hline
\end{tabular}


**. The mean difference is significant at the 0.01 level.

An inspection of Table 4 reveals that, the difference between the mean values of arts and commerce students is 1.31, and it is not significant even at 0.05 level. Commerce faculty students have slightly greater mean than arts students, but the difference is insignificant. Hence, the hypothesis 'Arts faculty students are significantly inferior to commerce faculty students in their environmental awareness' is partially rejected. It indicates that the arts students are inferior to commerce students, but not significantly inferior in their environmental awareness. Post hoc test also shows that the differences between the means of science and arts students (3.29), science and commerce students (1.98) are significant at 0.01 level. Science students have better mean than arts and commerce students. Thus, the hypothesis 'Science faculty students are significantly superior to arts and commerce faculty students in their environmental awareness' is accepted. It is evident that science faculty students have the knowledge and awareness about environmental issues, they are more aware than arts and commerce students.

This finding of the present study is in agreement with the studies conducted by Sengupta et al (2010) reported that science students have more environmental awareness in comparison to arts students because they are giving more importance to their curriculum pattern. Kumar et al (2011) revealed that science stream students have high environmental awareness scores than Arts stream students.

However, the results contradicts with the studies conducted by Ahuja (2010) and Bhavana (2011), which reveal that that there is no significant difference found between the mean scores of environment awareness of B.Ed. pupil teachers of Arts and Science streams.

\section{CONCLUSIONS}

On the basis of results the following conclusions were drawn:

1. Females have better environmental awareness than the males.

2. Arts students are not significantly inferior to commerce students on environmental awareness.

3. Science students are significantly superior to arts and commerce students on environmental awareness.

4. Sex and faculty are independently affected on environmental awareness, interaction effect is not significant. 


\section{REFERENCES}

1. Ahuja, P. L. (2010). A Study of Environmental Awareness Among B.Ed. Trainee Teachers of Govt. Aided and Self Financed Colleges. Shodh, Samiksha aur Mulyankan (International Research Journal), II (11-12), 28-30.

2. Bhawana.(2011).Environmental Awareness of B.Ed. Students. International Referred Research Journal, II (25),16-18.

3. Jha, P.K. (1998).Manual for Environment Awareness Ability Measure (EAAM).Agra: National Psychological Corporation.

4. Kumar, R., Malti, and Kumar, N. (2011).Environmental Awareness among Senior Secondary School Students. Indian Journal of Environmental Education, 11, 27-32.

5. Larijani, M.(2010).Assessment of Environmental Awareness among Higher Primary School Teachers. Journal of Human Ecology, 31(2), 121-124.

6. Sengupta, M., Das, J., and Maji, P.K.(2010).Environmental Awareness and Environment Related Behavior of Twelfth Grade Students in Kolkata: Effects of Stream and Sex. Anwesa, 5, 1 - 8 .

7. Shobeiri, S. M., Omidvar, B., and Prahallada, N.N.(2007).A comparative study of environmental awareness and attitude of teachers and students of secondary schools in India and Iran. International Journal of Environment Research.1 (1), 28-34. 